\title{
Mutation analysis of genes in the EGFR pathway in Head and Neck cancer patients: implications for anti-EGFR treatment response
}

Carolien Boeckx ${ }^{1 *}$, Christine Weyn ${ }^{1}$, Isabelle Vanden Bempt ${ }^{2}$, Vanessa Deschoolmeester ${ }^{1}$, An Wouters ${ }^{1}$, Pol Specenier ${ }^{3}$, Carl Van Laer ${ }^{4}$, Danielle Van den Weyngaert ${ }^{5}$, Mark Kockx ${ }^{2}$, Jan B Vermorken ${ }^{3}$, Marc Peeters ${ }^{1,3}$, Patrick Pauwels ${ }^{1,6}$, Filip Lardon ${ }^{1}$ and Marc Baay ${ }^{1}$

\begin{abstract}
Background: Targeted therapy against the Epidermal Growth Factor Receptor (EGFR) is among the most promising molecular therapeutics for Head and Neck Squamous Cell Carcinoma (HNSCC). However, drug resistance limits the clinical efficacy of anti-EGFR monoclonal antibodies and no predictive biomarker has entered the clinic yet.

Methods: A retrospective clinical study was performed utilizing pathological specimens from 52 newly diagnosed HNSCC patients. These patients were screened for mutations in EGFR and KRAS. Tyrosine kinase mutations in EGFR and KRAS mutations were evaluated by high resolution melting analysis (HRMA), whereas EGFRvIII was determined using one-step real-time PCR. Finally, patient samples were screened for HPV-DNA by GP5+/6+ PCR. Survival analysis was performed using Kaplan-Meier analysis and significance was calculated using log-rank statistic.

Results: In our study population no EGFRvIll mutations were present. However, two silent mutations were found; T785T in exon 20 and R836R in exon 21 of the EGFR gene. Additionally, HRMA revealed an abnormal KRAS melting pattern in $7.0 \%$ of the samples. However, the KRAS StripAssay could confirm only one sample with a G12S mutation and none of these samples could be confirmed by direct sequencing. HPV DNA was present in 3/25 larynx and 9/27 oropharynx tumors.
\end{abstract}

Conclusion: The low rate of EGFR and KRAS mutations in this Belgian HNSCC population suggests that these genes will probably not play a major role in predicting response to anti-EGFR therapy in HNSCC. Hence, other predictive markers need to be discovered in order to optimize EGFR targeting therapy.

Keywords: Head neck squamous cell carcinoma, EGFR inhibitors, Cetuximab, Resistance, KRAS mutations, EGFRvIII mutations, EGFR tyrosine kinase mutations, HPV

\section{Background}

Head and neck squamous cell carcinoma (HNSCC) is a heterogeneous and complex disease, having a severe impact on the quality of life of patients and survivors [1]. At time of diagnosis, 60 to $70 \%$ of patients present with advanced disease, affecting the survival of these patients negatively [2]. In up to $90 \%$ of HNSCC tumors, increased expression of the epidermal growth factor receptor (EGFR) is observed [3-5]. Increased EGFR expression

\footnotetext{
* Correspondence: carolien.boeckx@uantwerpen.be

${ }^{1}$ Center for Oncological Research (CORE) Antwerp, Laboratory of Cancer Research and Clinical Oncology, University of Antwerp, Wilrijk, Belgium Full list of author information is available at the end of the article
}

is associated with advanced stage of the disease, poor survival and resistance to chemo- and radiotherapy [3,6]. In only $50 \%$ of HNSCC patients, the current conventional treatment strategies, including surgery, chemotherapy and radiation, are effective, underscoring the need for new approaches to treat this malignancy $[7,8]$. Moreover, the existing cytotoxic therapies are non-selective and associated with considerable toxicity. Therefore, personalized medicine using targeted therapies will hopefully achieve the much-needed progress in HNSCC treatment.

As EGFR signaling plays an important role in the development and progression of HNSCC, it is one of the most promising targets for molecular targeted therapies 
[3-5]. The addition of cetuximab to platinum-fluorouracil chemotherapy, for instance, improved overall survival when given as first-line treatment in patients with recurrent or metastatic HNSCC [9]. However, resistance to EGFR inhibitors presents a therapeutic challenge, since intrinsic as well as acquired resistance after initial response has been described frequently [10]. Therefore, it is important to understand the mechanism of intrinsic resistance, as a further selection of patients who might benefit from the addition of cetuximab will increase its beneficial effect and most likely its cost-effectiveness.

In other forms of cancer where anti-EGFR therapy is used, molecular profiling of the tumor has become essential for customized medical treatment decision. EGFR and KRAS mutations strongly influence the benefit of treatment with anti-EGFR therapies, such as panitumumab and cetuximab used for treating metastatic colorectal cancer (mCRC) and tyrosine kinase inhibitors (TKIs) used for advanced non-small cell lung cancer (NSCLC) [11-14]. Although several reports have described EGFR and KRAS mutations in HNSCC, the mutation frequency can differ among ethnic groups. In the present study we aimed to correct for the heterogeneous nature of this disease by including only HNSCC patients eligible for cetuximab therapy and suffering from two common subtypes of HNSCC (oropharynx and larynx). Moreover, since infection with human papillomavirus (HPV) is a driver of HNSCC carcinogenesis, and HPV-positive cancers form a distinct group with better clinical outcome within HNSCC $[15,16]$, we determined the presence of HPV infection as well.

\section{Methods}

\section{Patient samples}

Formalin fixed, paraffin-embedded (FFPE) tissues from 52 newly diagnosed HNSCC patient samples (27 oropharyngeal and 25 laryngeal SCC) were retrieved from the department of Pathology, Antwerp University Hospital (Edegem, Belgium). The tissues were obtained from biopsies or resections performed between 2002 and 2010. At that time, all patients agreed that residual material from resections was used for studies (consented at the time of hospitalization); no recurrent approval from the local ethic committee was required. As EGFR targeted therapies are approved in patients with locally advanced or recurrent/metastatic disease, our patients were selected for stage III or higher to most accurately resemble this population.

\section{Screening of EGFR tyrosine kinase and KRAS mutations}

Prior to DNA extraction, tumor tissue was enriched by manual macrodissection and isolated using the QIAamp ${ }^{\circ}$ DNA FFPE Tissue isolation kit (Qiagen, Venlo, The Netherlands). Concentration and purity were defined using the Nanodrop ND-1000 spectrophotometer (Isogen, Sint-Pieters-Leeuw, Belgium).

Genomic DNA from patients was used for mutation analysis in the KRAS gene and EGFR tyrosine kinase domain by high resolution melting analysis (HRMA). Screening of mutations in exon 2 (codon 12 and 13) of the KRAS gene was performed as described previously [17]. Patient samples with an abnormal melting pattern were subjected to KRAS StripAssay (ViennaLab Diagnostics GmbH, Vienna, Austria), according to the manufacturer's recommendation. This assay screens for $10 K R A S$ mutations in codon 12 and 13 of exon 2.

Additional DNA was isolated from patients suspected of KRAS mutations, amplified by PCR and sequenced using Sanger sequencing. Primers for the 178-bp amplicon of exon 2 were 5'-GTAAAACGACGGCCAGGTGTGACA 'TGTTCTAATATAG-3' (forward) and 5'-TTGGATCA TATTCGTCCACAA-3' (reverse). PCR reaction was performed in $25 \mu \mathrm{l}$ reaction containing $1 \times$ buffer, $1 \mathrm{mM}$ $\mathrm{MgCl}_{2}, 0.5 \mu \mathrm{M}$ of each primer, $0.25 \mathrm{mM}$ dNTPs, $1 \mu \mathrm{l} \mathrm{Taq}$ polymerase and $5 \mu \mathrm{l}$ genomic DNA $(10 \mathrm{ng} / \mu \mathrm{l})$. PCR cycling was performed on a Px2 Thermal Cycler (Thermo Electron Corporation) and was run as follows: 15 minutes at $95^{\circ} \mathrm{C}$ and 35 cycles of 60 seconds at $94^{\circ} \mathrm{C}, 60$ seconds at $55^{\circ} \mathrm{C}$ and 60 seconds at $72^{\circ} \mathrm{C}$, followed by 10 minutes at $72^{\circ} \mathrm{C}$. This PCR product was purified using ExoSAP-IT (Affymetrix, Cleveland, OH, USA) and for validation, this product was used as template for direct sequencing with the Big Dye Terminator v1.1 kit (Applied Biosystems, Foster City, CA, USA) using M13tag primers (Eurogentec, Seraing, Belgium). The reaction mixture consisted of $1.1 \times$ sequencing buffer, $0.2 \mu$ l Big Dye mix, 625 nM M13tag primer 5'-GTAAAACGACGGCCAG3 ' and $1 \mu \mathrm{l}$ of purified template in a total volume of $4 \mu \mathrm{l}$. The reaction was run on a Rapid Cycler Instrument 2 (Idoha Technology Inc., Salt Lake City, UT, USA) according to the following protocol: initial denaturation at $95^{\circ} \mathrm{C}$ for $30 \mathrm{sec}$ and 25 cycles in the following sequence: $96^{\circ} \mathrm{C}$ for $10 \mathrm{sec}, 50^{\circ} \mathrm{C}$ for $5 \mathrm{sec}$ and $60^{\circ} \mathrm{C}$ for $2 \mathrm{~min}$. The sequencing reactions were run on a 3130 XL Genetic Analyzer (Applied Biosystems). Sequencing data were analyzed using SeqScanner software v1.0 (Applied Biosystems).

Primers and reaction conditions for detection of EGFR tyrosine kinase mutations in exon 19, 20 and 21 were adapted from Heideman et al. [18]. Amplification and generation of melting curves were performed on a Lightcycler ${ }^{\odot}$ 480 (Roche Diagnostics Gmbh, Mannheim, Germany) and analyzed using GeneScanning software (Roche). HRMA products with a deviating EGFR melting pattern were directly purified using ExoSAP-IT (Affymetrix) and the purified PCR product was used as template for direct Sanger sequencing (Big Dye Terminator v1.1 kit (Applied Biosystems,)) using M13tag primers, as described above. 
EGFRvIll mutation detection using real-time PCR

The determination of EGFRvIII mRNA expression was performed by semi-quantitative real-time PCR. Total RNA was obtained from FFPE tumor tissue with the High Pure RNA Paraffin Isolation kit (Roche) according to the manufacturer's recommendation. Prior to extraction, manual macrodissection was performed to enrich the sample for tumor cells.

After extraction, one-step real-time PCR was performed on the LightCycler 480 I instrument (Roche) using TaqMan RNA amplification kit (Roche). Thereby, 2 PCR reactions were performed, one for the specific amplification of EGFRvIII mRNA using a primer set targeting EGFR exon 1 and exon 8 (EGFRe1/8) and the other one for the amplification of total EGFR mRNA using a primer set targeting an unaffected region of the EGFR gene (exon 9 and 10, EGFRe9/10). The primer pairs are given in Table 1. For the detection of the EGFRvIII product, a fluorescently labeled oligonucleotide TaqMan probe (Eurogentec) was used. For the detection of total EGFR PCR product, YOPRO intercalating dye (Invitrogen, Merelbeke, Belgium) was used. Concentrated samples were diluted to a maximum of $20 \mathrm{ng} / \mu \mathrm{l}$. The input varied between $18.5 \mathrm{ng}$ and $100 \mathrm{ng}$. RNA template was added in a reaction mix consisting of $300 \mathrm{nM}$ forward and reverse primer each, $3 \mathrm{mM} \mathrm{Mn}^{2+}$, $0.1 \mathrm{mM}$ YoPro (EGFRe9/10 reaction) or $200 \mathrm{mM}$ TaqMan probe (EGFRe1/8 reaction), 1× RNA mix (TaqMan RNA amplification kit, Roche) in a total volume of $25 \mu \mathrm{l}$. Samples were run in duplicate.

As positive control, mRNA derived from an EGFRvIII mutant glioblastoma cell line U87del (kind gift from dr. Furnari from the Ludwig Institute for Cancer Research, La Jolla, CA, USA) was used. The cycling conditions are shown in Table 2. Data were analyzed using the Lightcycler 480 software release 1.5.0 software (Roche).

\section{HPV detection}

HPV detection by GP5+/6+ PCR was carried out on all 52 HNSCC samples, as described previously [19]. Detection of PCR products was performed in an enzyme immunoassay format as described by Jacobs et al. [20].

\section{Statistical analysis}

All experimental data were the combined result of at least two independent experiments. Prognostic relevance of HPV infection was assessed by survival analysis using the Kaplan-Meier method and survival curves were analyzed using the log-rank test. The index date for survival time calculation was defined as the date of diagnostic confirmation for HNSCC. The days of observation (overall survival time) were calculated from the index date to the date of last information/death. For progression free survival time, the days of observation were calculated from the index date to the first date of progression, death or the date of last information. All analyses were conducted using SPSS (version 20, SPSS Inc., Brussels, Belgium). Significance for all statistics was recorded if $\mathrm{p}<0.05$.

\section{Results}

\section{Patient characteristics}

Of the 52 HNSCC patients from whom tumor tissue could be obtained, most clinical data could be retrieved. Further details on these patients are summarized in Table 3.

\section{EGFR mutation analysis: EGFR tyrosine kinase and EGFRvIll mutation}

HRMA was used as a first-line screening method for EGFR tyrosine kinase mutations. DNA samples yielding a sufficiently high DNA concentration and good purity were screened for mutations in exon 19 to 21 of the EGFR gene. In total, $46 \mathrm{HNSCC}$ patient samples were available for EGFR mutation screening. Failure to generate a melting curve was present in 7, 7, 5 and 10 samples for exon 19, 20p, 20d and 21 , respectively. HRMA could not detect any aberrant melting curves in exon 19, whereas in exons 20 and 21 abnormal melting curves were detected. Therefore, these samples were sequenced in order to confirm and determine the mutation. Although we did not detect any missense mutations, two patients were found with a silent mutation; T785T (exon 20p) and R836R (exon 21) (Figure 1A and 1B).

Furthermore, screening for EGFRvIII mutations was performed by one-step real-time reverse transcriptase PCR. Of the 52 HNSCC samples, 8 failed to amplify. In the remaining $44 \mathrm{HNSCC}$ samples, no EGFRvIII mutations could be detected.

\section{KRAS mutation}

Similar to the screening method of EGFR tyrosine kinase mutations, we screened for mutations in codon 12 and

Table 1 Primers (Eurogentec) used for detection of EGFRvIll by real-time PCR

\begin{tabular}{|c|c|c|c|c|}
\hline Oligo name & Oligo type & Mod5' & Sequence & Mod3' \\
\hline EGFRe1-F & forward primer & & GAGTCGGGCTCTGGAGGAA & \\
\hline EGFRe8-R & reverse primer & & GGCCCTTCGCACTTCTTACA & \\
\hline EGFRe1/8-TM & TaqMan probe & $6-F A M$ & AAAGGTAATTATGTGGTGACAGATCACGGCTC & $\mathrm{BHQ}-1$ \\
\hline EGFRe9/10-F & forward primer & & TCCTGCCGGTGGCATT & \\
\hline EGFRe9-R & reverse primer & & TGTGGATCCAGAGGAGGAGTATG & \\
\hline
\end{tabular}


Table 2 Cycling condition for one-step RT-PCR

\begin{tabular}{llll}
\hline Stage & Temperature & Time & \# cycles \\
\hline Stage I preheating & $95^{\circ} \mathrm{C}$ & $1 \mathrm{~min}$ & 1 \\
$\begin{array}{l}\text { Stage II: reverse } \\
\text { transcription }\end{array}$ & $60^{\circ} \mathrm{C}$ & $30 \mathrm{~min}$ & 1 \\
Stage III: activation & $95^{\circ} \mathrm{C}$ & $10 \mathrm{~min}$ & 1 \\
Stage IV: cycling & $95^{\circ} \mathrm{C}$ & $15 \mathrm{seC}$ & 45 \\
& $60^{\circ} \mathrm{C}$ & $1 \mathrm{~min}$ & \\
Stage V: denaturation & $95^{\circ} \mathrm{C}$ & $1 \mathrm{~min}$ & \\
Stage VI: melting & $50^{\circ} \mathrm{C}-85^{\circ} \mathrm{C}$ & Continues measuring \\
Stage VII: cool & $40^{\circ} \mathrm{C}$ & $30 \mathrm{sec}$ &
\end{tabular}

13 of the KRAS gene using HRMA. Of the 52 HNSCC samples, five could not be used for screening due to reduced DNA concentration or insufficient purity of the DNA samples. Another 4 samples failed to generate a melting curve; hence no mutation status could be determined. Of the remaining 43 HNSCC patients, three samples presented with an aberrant melting profile, consistent with the positive control (KRAS mutated cell line), see Figure 2 . The other 37 samples were wild type for codon 12 and 13 of the KRAS gene, as determined by HRMA.

For validation, these three samples were subjected to further analysis using the KRAS StripAssay ${ }^{\circ}$. These results showed a very weak band for the G12S mutations (green curve in Figure 2) for one sample, one other sample was wild type for 10 KRAS mutations (yellow curve in Figure 2) and one sample could not be evaluated due to failure of the test (blue curve in Figure 2). To further confirm these results, additional DNA was isolated for KRAS mutation screening by dideoxy sequencing for these three samples. Surprisingly, all samples showed the wild type GGTGGC sequence.

\section{HPV infection in oropharygeal and laryngeal cancer}

Screening of our HNSCC patient population identified 12 out of $52 \mathrm{HPV}$ positive HNSCC tumors (23.1\%), nine tumors were located in the oropharynx (33.3\%) and three in the larynx (12.0\%).

Statistical analysis did not show any significant survival benefit (overall survival and progression free survival) for patients with HPV-related HNSCC tumors, $\mathrm{p}=0.125$ and $\mathrm{p}=0.374$ respectively (Figure $3 \mathrm{~A}$ and $\mathrm{B}$ ).

\section{Discussion}

As personalized cancer medicine - in particular drugs based on genetics - will become more and more important in the future, molecular profiling of the tumor prior to treatment becomes essential. Unfortunately, no predictive biomarker for the promising anti-EGFR therapeutics in the treatment of HNSCC has entered the clinic yet.
Table 3 Clinical data from 52 HNSCC patients

\begin{tabular}{|c|c|c|c|}
\hline & Oropharynx & Larynx & Overall population \\
\hline \multicolumn{4}{|l|}{ Patient characteristics } \\
\hline Total no. of patients & 27 & 25 & 52 \\
\hline Median age (years) & 62.75 & 62.17 & 62.58 \\
\hline \multicolumn{4}{|l|}{ Sex } \\
\hline Male & 21 & 21 & 42 \\
\hline Female & 6 & 4 & 10 \\
\hline \multicolumn{4}{|l|}{ Grade of differentiation } \\
\hline Good & 4 & 7 & 11 \\
\hline Moderate & 17 & 10 & 27 \\
\hline Poor & 0 & 1 & 1 \\
\hline Unknown & 6 & 7 & 13 \\
\hline \multicolumn{4}{|l|}{ TNM } \\
\hline $\mathrm{T} 1$ & 2 & 0 & 2 \\
\hline $\mathrm{T} 2$ & 6 & 0 & 6 \\
\hline T3 & 5 & 10 & 15 \\
\hline T4 & 14 & 15 & 29 \\
\hline NO & 5 & 12 & 14 \\
\hline N1 & 1 & 5 & 6 \\
\hline $\mathrm{N} 2$ & 17 & 6 & 23 \\
\hline N3 & 3 & 2 & 5 \\
\hline $\mathrm{Nx}$ & 1 & 0 & 1 \\
\hline Mo & 21 & 22 & 43 \\
\hline M1 & 3 & 2 & 5 \\
\hline$M x$ & 3 & 1 & 4 \\
\hline \multicolumn{4}{|l|}{ Stage } \\
\hline III & 3 & 8 & 11 \\
\hline Iva & 19 & 13 & 32 \\
\hline $\mathrm{IVb}$ & 4 & 2 & 6 \\
\hline IVC & 1 & 2 & 3 \\
\hline \multicolumn{4}{|l|}{ Smoking } \\
\hline Yes & 9 & 6 & 15 \\
\hline Ex & 4 & 6 & 10 \\
\hline No & 1 & 0 & 1 \\
\hline Unknown & 13 & 13 & 26 \\
\hline \multicolumn{4}{|l|}{ Alcohol abuse } \\
\hline Yes & 7 & 7 & 14 \\
\hline Ex & 1 & 1 & 2 \\
\hline No & 3 & 2 & 5 \\
\hline Unknown & 16 & 15 & 31 \\
\hline
\end{tabular}

Pinpointing mechanisms of resistance to EGFR targeting agents in HNSCC has proven difficult due to several factors. First, HNSCC is a heterogeneous disease, affecting several anatomical structures located within the head 


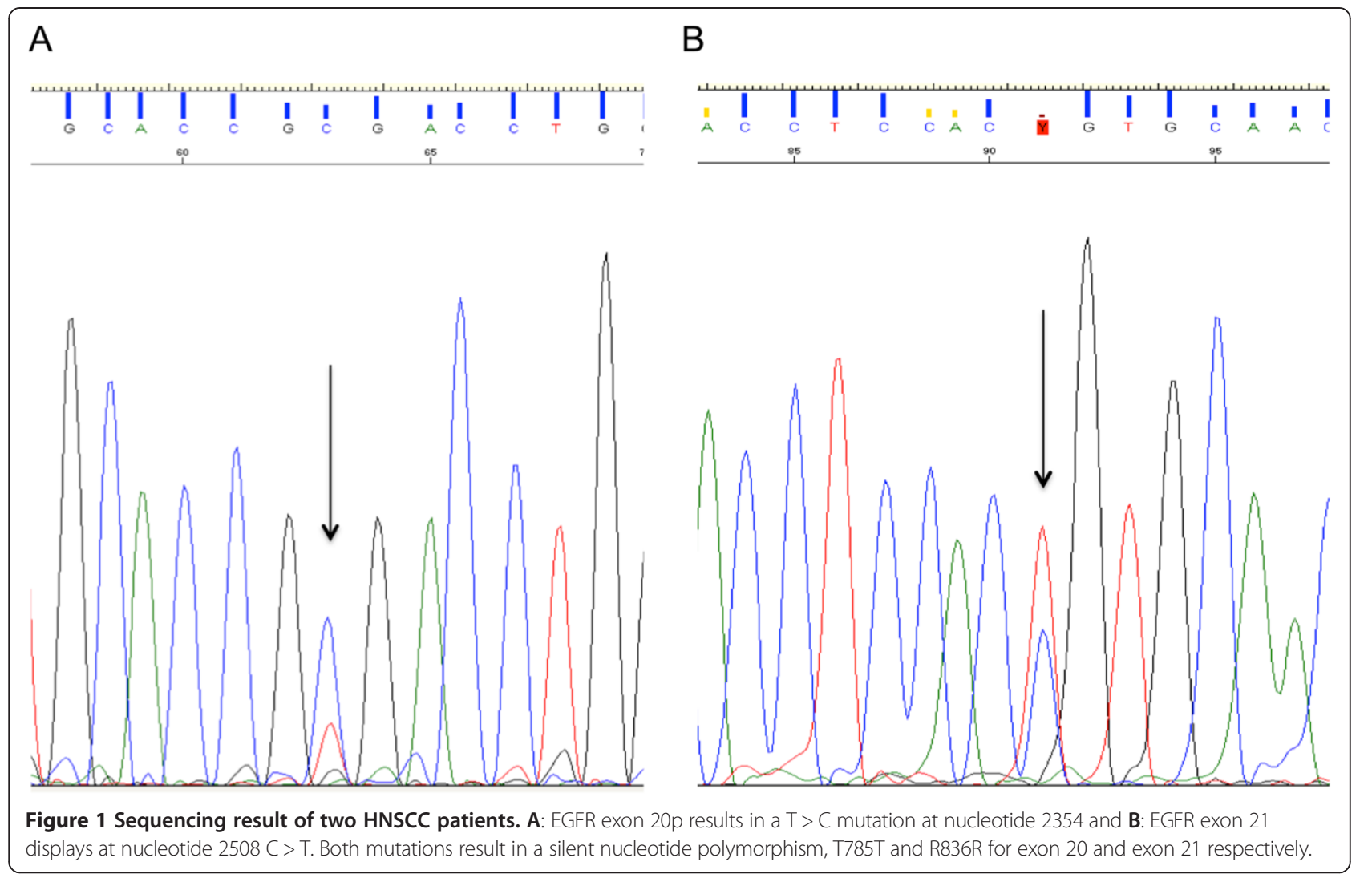

and neck region. Second, mutation frequencies might vary between different ethnic groups. And finally, stages of tumors might be characterized by certain mutations. Therefore, we tried to correct for these factors by including only Caucasian laryngeal and oropharyngeal tumors eligible for cetuximab therapy and evaluated whether the mutation frequencies are in line with the frequencies reported in the literature. Furthermore, we determined the incidence of HPV in these 52 HNSCC patients as well.

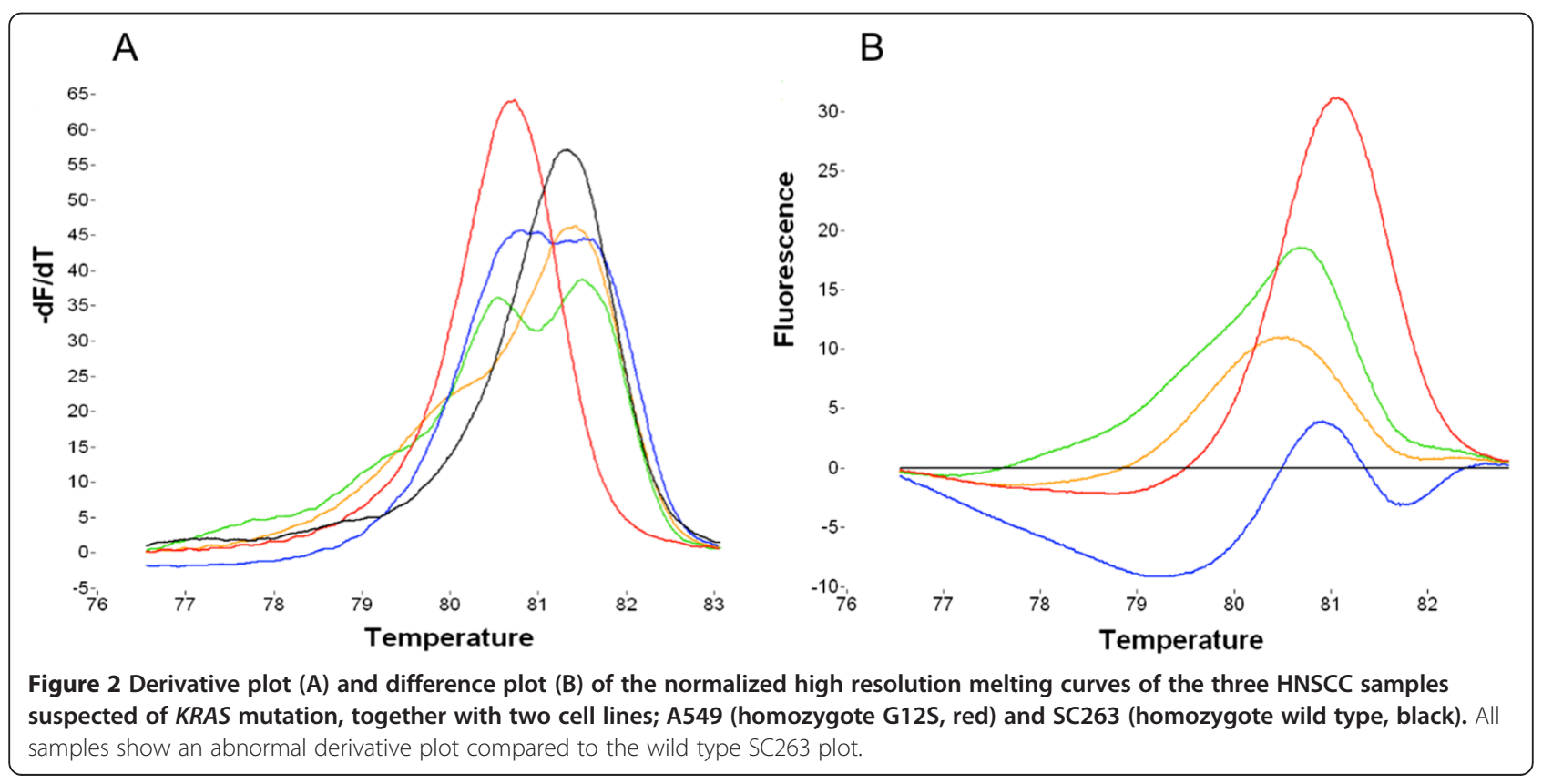



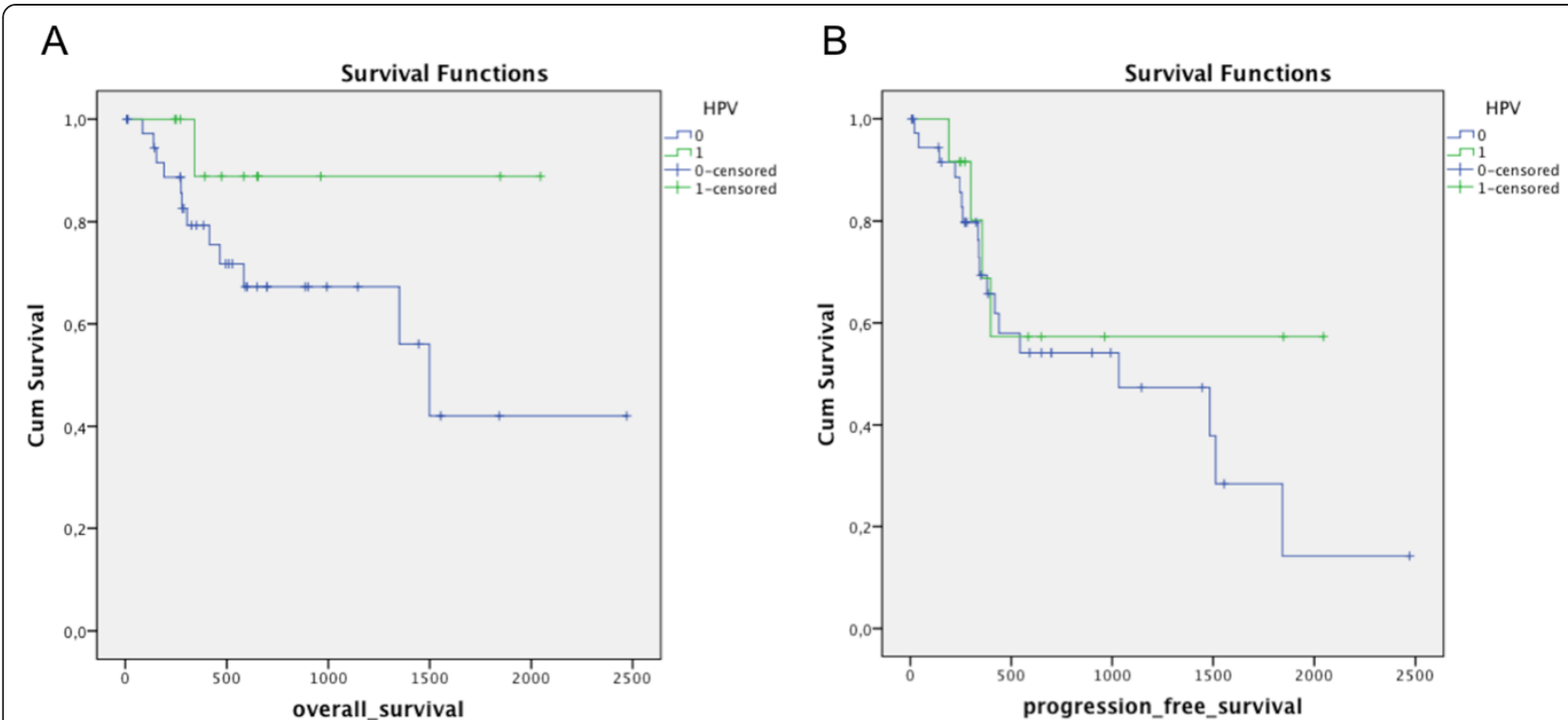

Figure 3 Kaplan-Meier survival analysis for HPV infection in HNSCC for overall survival (A) and progression free survival (B). Significance was calculated using log-rank statistic ( $p=0.125$ and $p=0.374$, respectively).

Sustained EGFR signaling can be elicited at different levels in the signaling cascade, including at the level of the target itself. Compensatory mutations in the tyrosine kinase domain of EGFR or the constitutively active and truncated form of EGFR (i.e. EGFRvIII) are shown to predict response to anti-EGFR therapy in other tumor types $[13,14,21,22]$. We observed no EGFR tyrosine kinase missense mutations, although two silent mutations (T785T and R836R) were detected. These results indicate that EGFR tyrosine kinase mutations are uncommon in this Belgian HNSCC patient population. This is in concordance with literature where mutation frequencies vary between 0 and $8 \%$ [23-25]. On the other hand, Murray et al. detected an EGFR tyrosine kinase mutation frequency of $15.8 \%$, albeit in a small sample population $(n=19)$ [5]. The EGFRvIII mutation has been reported previously in HNSCC by real-time PCR and immunohistochemistry. However, subsequent studies have provided conflicting evidence $[11,16,26,27]$. In these studies, the EGFRvIII mutation frequency in HNSCC varies between $0 \%$ and $42 \%$. In our study population, no EGFRvIII mutations could be detected using one-step real-time PCR on FFPE material.

KRAS serves as a mediator between extracellular ligand binding and intracellular transduction of signals from EGFR to the nucleus. Therefore, aberrant expression of KRAS might result in sustained EGFR signaling despite inhibition. The KRAS mutation frequency in HNSCC observed in literature varies between 0 and $6 \%$ $[23,26,28]$. This study identified three out of 43 samples with an aberrant HRMA melting profile. Although these samples showed aberrant melting profiles, indicative of the presence of low level sequence variants, no mutations could be identified with Sanger sequencing and only one (G12S mutation) could be confirmed with the KRAS AssayStrip. These conflicting results can be explained by two main factors, which influence test results. First, genetic heterozygosity within the tumor might result in mutation levels below the analytical sensitivity of dideoxy sequencing $(10-30 \%)[17,29]$, whereas the detection limit of HRMA was previously reported at $3 \%$ [17] and the KRAS StripAssay detect at least 1\% mutated alleles. Second, the DNA used in this study was extracted from FFPE sections and formalin fixation has adverse effects on DNA. Consequently, Taq polymerase errors can cause PCR artifacts during amplification $[29,30]$. Therefore, positive samples were repeated by an independent round of DNA isolation and amplification, to avoid false positive results. However, it was not possible to make a distinction between low-level mutations and sequence artifacts by formalin fixation, as fresh frozen tissue from these patients was unfortunately not available.

As HPV positive HNSCC tumors tend to have a more favorable outcome, we screened our 52 patients for HPV DNA. In this Belgian study population, $33.3 \%$ of the oropharyngeal cancer and $12.0 \%$ of the laryngeal tumors contained HPV DNA. Frequencies reported in literature can range from $0 \%$ to $100 \%$ [31-33], depending on several factors, including differences in ethno-geographic regions, combination of different subtypes of HNSCC and differences in the applied HPV detection methods [34-36]. Our study was not designed to confirm the association between HPV positive HNSCC tumors and improved survival, and consequently, did not take into 
account other factors influencing prognosis. Therefore, no conclusions regarding HPV positive HNSCC tumors and overall survival can be made. Furthermore, the value of cetuximab in HPV-related HNSCC is unclear. Recent data challenge the role of cetuximab therapy in HPV positive oral squamous cell carcinoma [37,38]. Therefore, the role of cetuximab in treatment of HPV-associated HNSCC needs to be explored in prospective clinical trials.

\section{Conclusion}

To conclude, this retrospective study detected two silent EGFR tyrosine kinase mutations and no EGFRvIII mutations. Due to discrepancy between HRMA and sequencing results, KRAS mutation frequency varies from $0.0 \%$ to $7.0 \%$. Although the mutation status of EGFR and KRAS are used as predicting biomarkers for EGFR targeted therapy in other tumor types, their (extremely) low prevalence in HNSCC will likely preclude a major role in helping to define treatment options in these patients. Therefore, other genes are likely involved in resistance to anti-EGFR therapy in HNSCC and more in-depth-studies are needed to unravel these mechanisms.

\section{Abbreviations}

EGFR: Epidermal growth factor receptor; HNSCC: Head and neck squamous cell carcinoma; HRMA: High resolution melting analysis; mCRC: Metastatic colorectal cancer; TKIs: Tyrosine kinase inhibitors; NSCLC: Non-small cell lung cancer; HPV: Human papilloma virus; FFPE: Formalin-fixed paraffin embedded.

\section{Competing interests}

Jan B. Vermorken: Merck-Serano (consulting/advisory relationship, honoraria, travel compensation); Bristol-Myers Squibb (honoraria, travel compensation); Lilly (travel compensation). Marc Peeters: Amgen/Merck-Serono (consulting/ advisory relationship, research funding, honoraria). The other authors declare that they have no competing interests.

\section{Authors' contributions}

$\mathrm{CB}$ carried out the KRAS mutation study, performed the statistical analysis and drafted the manuscript. CW and PP carried out the EGFR tyrosine kinase mutation study. IVB and MK carried out the EGFRvIII mutation study. MB participated in the design and coordination of the study, carried out the HPV detection and helped to draft the manuscript. DVD, CVL and PP provided clinical samples and clinicopathological data. VD, AW, PS, MP and FL participated in the design and coordination of the study. All authors read and approved the final manuscript.

\section{Acknowledgments}

AW holds a postdoctoral fellowship from the FWO (Fonds voor Wetenschappelijk Onderzoek) Vlaanderen. We would like to thank Céline Quix for excellent technical assistance

\footnotetext{
Author details

${ }^{1}$ Center for Oncological Research (CORE) Antwerp, Laboratory of Cancer Research and Clinical Oncology, University of Antwerp, Wilrijk, Belgium. ${ }^{2}$ HistoGeneX, Berchem, Belgium. ${ }^{3}$ Department of Medical Oncology, Antwerp University Hospital, Edegem, Belgium. ${ }^{4}$ Department of Otolaryngology, Antwerp University Hospital, Edegem, Belgium. ${ }^{5}$ Department of Radiation Therapy, Antwerp University Hospital, Edegem, Belgium. ${ }^{6}$ Department of Pathology, Antwerp University Hospital, Edegem, Belgium.
}

Received: 23 March 2014 Accepted: 29 May 2014

Published: 4 June 2014

\section{References}

1. Graziano A, d'Aquino R, Tirino V, Desiderio V, Rossi A, Pirozzi G: The stem cell hypothesis in head and neck cancer. J Cell Biochem 2008, 103(2):408-412.

2. Vermorken JB, Specenier P: Optimal treatment for recurrent/metastatic head and neck cancer. Ann Oncol 2010, 21(Suppl 7):vii252-vii261.

3. Temam S, Kawaguchi H, El-Naggar AK, Jelinek J, Tang H, Liu DD, Lang W, Issa JP, Lee JJ, Mao L: Epidermal growth factor receptor copy number alterations correlate with poor clinical outcome in patients with head and neck squamous cancer. J Clin Oncol 2007, 25(16):2164-2170.

4. Ang KK, Berkey BA, Tu X, Zhang HZ, Katz R, Hammond EH, Fu KK, Milas L: Impact of epidermal growth factor receptor expression on survival and pattern of relapse in patients with advanced head and neck carcinoma. Cancer Res 2002, 62(24):7350-7356.

5. Murray S, Bobos M, Angouridakis N, Nikolaou A, Linardou H, Razis E, Fountzilas G: Screening for EGFR Mutations in Patients with Head and Neck Cancer Treated with Gefitinib on a Compassionate-Use Program: A Hellenic Cooperative Oncology Group Study. J Oncol 2010, 2010:709678.

6. Dittmann K, Mayer C, Rodemann HP: Nuclear EGFR as novel therapeutic target: insights into nuclear translocation and function. Strahlenther Onkol 2010, 186(1):1-6.

7. Molinolo AA, Amornphimoltham P, Squarize CH, Castilho RM, Patel V, Gutkind JS: Dysregulated molecular networks in head and neck carcinogenesis. Oral Oncol 2009, 45(4-5):324-334.

8. Boehm AL, Sen M, Seethala R, Gooding WE, Freilino M, Wong SM, Wang S, Johnson DE, Grandis JR: Combined targeting of epidermal growth factor receptor, signal transducer and activator of transcription-3, and $\mathrm{Bcl}-\mathrm{X}(\mathrm{L})$ enhances antitumor effects in squamous cell carcinoma of the head and neck. Mol Pharmacol 2008, 73(6):1632-1642.

9. Vermorken JB, Mesia R, Rivera F, Remenar E, Kawecki A, Rottey S, Erfan J, Zabolotnyy D, Kienzer HR, Cupissol D, Peyrade F, Benasso M, Vynnychenko I, De Raucourt D, Bokemeyer C, Schueler A, Amellal N, Hitt R: Platinum-based chemotherapy plus cetuximab in head and neck cancer. $N$ Engl J Med 2008, 359(11):1116-1127.

10. Boeckx C, Baay M, Wouters A, Specenier P, Vermorken JB, Peeters M, Lardon F: Anti-epidermal growth factor receptor therapy in head and neck squamous cell carcinoma: focus on potential molecular mechanisms of drug resistance. Oncologist 2013, 18(7):850-864.

11. Sok JC, Coppelli FM, Thomas SM, Lango MN, Xi S, Hunt JL, Freilino ML, Graner MW, Wikstrand CJ, Bigner DD, Gooding WE, Furnari FB, Grandis JR: Mutant epidermal growth factor receptor (EGFRvIII) contributes to head and neck cancer growth and resistance to EGFR targeting. Clin Cancer Res 2006, 12(17):5064-5073.

12. Lievre A, Bachet JB, Le Corre D, Boige V, Landi B, Emile JF, Cote JF, Tomasic G, Penna C, Ducreux M, Rougier P, Penault-Llorca F, Laurent-Puig P: KRAS mutation status is predictive of response to cetuximab therapy in colorectal cancer. Cancer Res 2006, 66(8):3992-3995.

13. Lynch TJ, Bell DW, Sordella R, Gurubhagavatula S, Okimoto RA, Brannigan BW, Harris PL, Haserlat SM, Supko JG, Haluska FG, Louis DN, Christiani DC, Settleman J, Haber DA: Activating mutations in the epidermal growth factor receptor underlying responsiveness of non-small-cell lung cancer to gefitinib. N Engl J Med 2004, 350(21):2129-2139.

14. Paez JG, Janne PA, Lee JC, Tracy S, Greulich H, Gabriel S, Herman P, Kaye FJ, Lindeman N, Boggon TJ, Naoki K, Sasaki H, Fujii Y, Eck MJ, Sellers WR, Johnson BE, Meyerson M: EGFR mutations in lung cancer: correlation with clinical response to gefitinib therapy. Science 2004, 304(5676):1497-1500.

15. Leemans CR, Braakhuis BJ, Brakenhoff RH: The molecular biology of head and neck cancer. Nat Rev Cancer 2011, 11(1):9-22.

16. Chau NG, Perez-Ordonez B, Zhang K, Pham NA, Ho J, Zhang T, Ludkovski O, Wang L, Chen EX, Tsao MS, Kamel-Reid S: The association between EGFR variant III, HPV, p16, c-MET, EGFR gene copy number and response to EGFR inhibitors in patients with recurrent or metastatic squamous cell carcinoma of the head and neck. Head Neck Oncol 2011, 3:11.

17. Deschoolmeester V, Boeckx C, Baay M, Weyler J, Wuyts W, Van Marck E, Peeters M, Lardon F, Vermorken JB: KRAS mutation detection and prognostic potential in sporadic colorectal cancer using high-resolution melting analysis. Br J Cancer 2010, 103(10):1627-1636.

18. Heideman DA, Thunnissen FB, Doeleman M, Kramer D, Verheul HM, Smit EF, Postmus PE, Meijer CJ, Meijer GA, Snijders PJ: A panel of high resolution melting (HRM) technology-based assays with direct sequencing possibility for effective mutation screening of EGFR and K-ras genes. Cell Oncol 2009, 31(5):329-333. 
19. de Roda Husman AM, Walboomers JM, van den Brule AJ, Meijer CJ, Snijders PJ: The use of general primers GP5 and GP6 elongated at their 3' ends with adjacent highly conserved sequences improves human papillomavirus detection by PCR. J Gen Virol 1995, 76(Pt 4):1057-1062.

20. Jacobs MV, van den Brule AJ, Snijders PJ, Helmerhorst TJ, Meijer CJ, Walboomers JM: A non-radioactive PCR enzyme-immunoassay enables a rapid identification of HPV 16 and 18 in cervical scrapes after GP5+/6+ PCR. J Med Virol 1996, 49(3):223-229.

21. Wachsberger PR, Lawrence RY, Liu Y, Rice B, Daskalakis C, Dicker AP: Epidermal growth factor receptor mutation status and rad51 determine the response of glioblastoma to multimodality therapy with cetuximab, temozolomide, and radiation. Front Oncol 2013, 3:13.

22. Lv S, Teugels E, Sadones J, De Brakeleer S, Duerinck J, Du Four S, Michotte A, De Greve J, Neyns B: Correlation of EGFR, IDH1 and PTEN status with the outcome of patients with recurrent glioblastoma treated in a phase II clinical trial with the EGFR-blocking monoclonal antibody cetuximab. Int J Oncol 2012, 41(3):1029-1035.

23. Van Damme N, Deron P, Van Roy N, Demetter P, Bols A, Van Dorpe J, Baert F, Van Laethem JL, Speleman F, Pauwels P, Peeters M: Epidermal growth factor receptor and K-RAS status in two cohorts of squamous cell carcinomas. BMC Cancer 2010, 10:189.

24. Loeffler-Ragg J, Witsch-Baumgartner M, Tzankov A, Hilbe W, Schwentner I, Sprinzl GM, Utermann G, Zwierzina H: Low incidence of mutations in EGFR kinase domain in Caucasian patients with head and neck squamous cell carcinoma. Eur J Cancer 2006, 42(1):109-111.

25. Willmore-Payne C, Holden JA, Layfield LJ: Detection of EGFR- and HER2activating mutations in squamous cell carcinoma involving the head and neck. Mod Pathol 2006, 19(5):634-640.

26. Szabo B, Nelhubel GA, Karpati A, Kenessey I, Jori B, Szekely C, Petak I, Lotz G, Hegedus Z, Hegedus B, Fule T, Dome B, Timar J, Tovari J: Clinical significance of genetic alterations and expression of epidermal growth factor receptor (EGFR) in head and neck squamous cell carcinomas. Oral Oncol 2011, 47(6):487-496.

27. Hama T, Yuza Y, Saito Y, Ou J, Kondo S, Okabe M, Yamada H, Kato T, Moriyama H, Kurihara S, Urashima M: Prognostic significance of epidermal growth factor receptor phosphorylation and mutation in head and neck squamous cell carcinoma. Oncologist 2009, 14(9):900-908.

28. Weber A, Langhanki L, Sommerer F, Markwarth A, Wittekind C, Tannapfel A: Mutations of the BRAF gene in squamous cell carcinoma of the head and neck. Oncogene 2003, 22(30):4757-4759.

29. Do H, Krypuy M, Mitchell PL, Fox SB, Dobrovic A: High resolution melting analysis for rapid and sensitive EGFR and KRAS mutation detection in formalin fixed paraffin embedded biopsies. BMC Cancer 2008, 8:142.

30. Pichler M, Balic M, Stadelmeyer E, Ausch C, Wild M, Guelly C, Bauernhofer T, Samonigg H, Hoefler G, Dandachi N: Evaluation of high-resolution melting analysis as a diagnostic tool to detect the BRAF V600E mutation in colorectal tumors. J Mol Diagn 2009, 11(2):140-147.

31. Syrjanen S: Human papillomaviruses in head and neck carcinomas. N Engl J Med 2007, 356(19):1993-1995.

32. Ha PK, Califano JA: The role of human papillomavirus in oral carcinogenesis. Crit Rev Oral Biol Med 2004, 15(4):188-196.

33. Evans M, Newcombe R, Fiander A, Powell J, Rolles M, Thavaraj S, Robinson M, Powell N: Human Papillomavirus-associated oropharyngeal cancer: an observational study of diagnosis, prevalence and prognosis in a UK population. BMC Cancer 2013, 13:220

34. Syrjanen S: Human papillomavirus (HPV) in head and neck cancer. J Clin Virol 2005, 32(Suppl 1):S59-S66.

35. Hobbs CG, Sterne JA, Bailey M, Heyderman RS, Birchall MA, Thomas SJ: Human papillomavirus and head and neck cancer: a systematic review and meta-analysis. Clin Otolaryngol 2006, 31(4):259-266.

36. Termine N, Panzarella V, Falaschini S, Russo A, Matranga D, Lo Muzio L, Campisi G: HPV in oral squamous cell carcinoma vs head and neck squamous cell carcinoma biopsies: a meta-analysis (1988-2007). Ann Oncol 2008, 19(10):1681-1690.

37. Psyrri A, Sasaki C, Vassilakopoulou M, Dimitriadis G, Rampias T: Future directions in research, treatment and prevention of HPV-related squamous cell carcinoma of the head and neck. Head Neck Pathol 2012, 6(Suppl 1):S121-S128.

38. Koutcher L, Sherman E, Fury M, Wolden S, Zhang Z, Mo Q, Stewart L, Schupak K, Gelblum D, Wong R, Kraus D, Shah J, Zelefsky M, Pfister D, Lee $\mathrm{N}$ : Concurrent cisplatin and radiation versus cetuximab and radiation for locally advanced head-and-neck cancer. Int J Radiat Oncol Biol Phys 2011, 81(4):915-922.

doi:10.1186/1756-0500-7-337

Cite this article as: Boeckx et al:: Mutation analysis of genes in the EGFR pathway in Head and Neck cancer patients: implications for anti-EGFR treatment response. BMC Research Notes 2014 7:337.

\section{Submit your next manuscript to BioMed Central and take full advantage of:}

- Convenient online submission

- Thorough peer review

- No space constraints or color figure charges

- Immediate publication on acceptance

- Inclusion in PubMed, CAS, Scopus and Google Scholar

- Research which is freely available for redistribution

Submit your manuscript at www.biomedcentral.com/submit
C BioMed Central 